\title{
ПРИРОДНО-СЕЛЬСКОХОЗЯЙСТВЕННОЕ РАЙОНИРОВАНИЕ ДЛЯ ЦЕЛЕЙ ОЦЕНКИ ЗЕМЕЛЬ
}

\section{Дмитрий Васильевич Морошкин}

Сибирский государственный университет геосистем и технологий, 630108, Россия, г. Новосибирск, ул. Плахотного, 10, обучающийся, тел. (923)158-82-02, e-mail: moroshkin.dmitri@yandex.ru

В статье рассматривается вопрос организации рационального использования, эффективного мониторинга состояния земель сельскохозяйственного назначения природного районирования территорий, а также рассмотрены проблемы законотворческой деятельности в рамках стратегического планирования использования земельных ресурсов.

Ключевые слова: стратегическое планирование, природно-сельскохозяйственное районирование, оценка земель сельскохозяйственного назначения, земельные отношения

\section{NATURAL AND AGRICULTURAL ZONING FOR THE PURPOSES OF THE VALUATION OF LAND}

\section{Dmitry $V$. Moroshkin}

Siberian State University of Geosystems and Technologies, 10, Plakhotnogo St., Novosibirsk, 630108, Russia, Student, phone: (923)158-82-02, e-mail: moroshkin.dmitri@yandex.ru

The article discusses the issue of organizing rational use, effective monitoring of the state of agricultural lands, natural zoning of territories, and considers the problems of lawmaking in the framework of strategic planning of the use of land resources.

Keywords: strategic planning, natural and agricultural zoning, assessment of agricultural land, land relations

Качество жизни людей напрямую зависит от использования земли, которая сочетает в себе качества природного ресурса и социально-общественных отношений. Эти качества являются связующим звеном в эволюционном развитии человека. Но с наступлением бурной индустриализации возникают проблемы сохранения земельных ресурсов. Законодательная деятельность органов государственной власти должна быть направлена на организацию и упорядочение земельных отношений, на укрепление политических ценностей, подчеркивающей значение земли в экономике как ресурсной и производственной базы.

На сегодняшний день во многих странах разработан механизм общественного воздействия на процессы землепользования и охраны земель. В Российской Федерации данный механизм базируется на нормативных правовых актах в области земельного законодательства, системе координируемых функций государственной власти по землеустройству [1].

Рациональное использование земельных ресурсов является основой экономического развития любого государства, основой пространственного и отраслевого развития. В условиях высокой конкуренции активного использования 
земельных ресурсов в Российской Федерации все более актуальным становится определение целей и задач государственной политики в области планирования и организации рационального использования земель и охраны. Для целей совершенствования стратегического планирования землепользования в соответствии с дальнейшими перспективами развития экономики, улучшения качества землеустройства территорий и определения иных направлений рационального использования земель и их охраны на национальном, региональном и муниципальном уровнях.

Природно-сельскохозяйственное районирование земель - это деление территории с учетом природных условий сельскохозяйственных образований и биологических требований к сельскохозяйственным культурам. Природное и сельскохозяйственное зонирование земель является основой для оценки планирования рационального землепользования и разработки землеустроительной документации.

Ключевые элементы стратегического планирования землепользования и охраны земельных ресурсов были заложены в 30-е годы XX века, при реализации мероприятий по освоению и введению новых земель для увеличения валового оборота страны, а также значительного увеличения орошаемых и осушаемых сельскохозяйственных угодий. Впоследствии, продолжая дальнейший курс землеустройства и освоения, в 50-е годы отмечаются программы освоения целинных и залежных земель. В принятых программах особое внимание уделялось защите сельскохозяйственных угодий от всех видов эрозии. В дальнейшем вектор развития законодательной деятельности изменился с принятием закона от 13.12.1968 № 3401-VII, предусматривающего установление долгосрочных планов рационального использования государственных земельных ресурсов, обеспечивающих потребности населения страны в сельскохозяйственной продукции и других отраслях народного хозяйства, установление планов разработки мероприятий по мелиорации земель, а также повышению уровня плодородия почв, при этом основные положения коснулись охраны земли. Долгосрочные пятилетние и годовые планы развития народного хозяйства по рациональному использованию природных ресурсов и охране земель начали реализовываться в 70 -е годы [2].

В настоящее время основополагающие правовые особенности землепользования отражены в Федеральном законе от 18.06.2001 № 78-Ф3, который предусматривает основные принципы землеустройства в целях обеспечения рационального использования земель и их охраны, а также создания благоприятной природной среды.

В соответствии со статьей 14 указанного закона раскрываются понятия планирования и организации рационального использования земель и их охраны, а также определяются основные виды работ, включающие природное и сельскохозяйственное районирование земель [3].

Положение о государственном земельном надзоре, утвержденное постановлением Правительства Российской Федерации от 02.01.2015 № 1, предусматривает внесение сведений землепользователями и землевладельцами в базу данных 
единой федеральной информационной системы по земельным ресурсам сельскохозяйственного назначения (ЕФИС ЗСН), что гарантирует владельцам (пользователям) земельных участков, ежегодно осуществляющим сельскохозяйственную деятельность и предоставляющим сведения о земельных участках в ЕФИС $3 \mathrm{CH}$, уменьшение налоговой базы по сельскохозяйственному налогу на осуществляемую сельскохозяйственную деятельность или установление пониженной ставки сельскохозяйственного налога.

Целями информационной системы ЕФИС ЗСН является информационноаналитическое обеспечение, консолидация сведений о землях сельскохозяйственного назначения, информационная поддержка управленческих решений.

Информационная система ЕФИС ЗСН содержит данные о виде сельскохозяйственных угодий контура, фактических границах сельскохозяйственных угодий, плодородии почв и негативных процессах. С помощью алгоритмов информационной системы ЕФИС ЗСН возможно проводить инвентаризацию земель сельскохозяйственного назначения, выявлять неиспользуемые земельные участки (рис. 1).

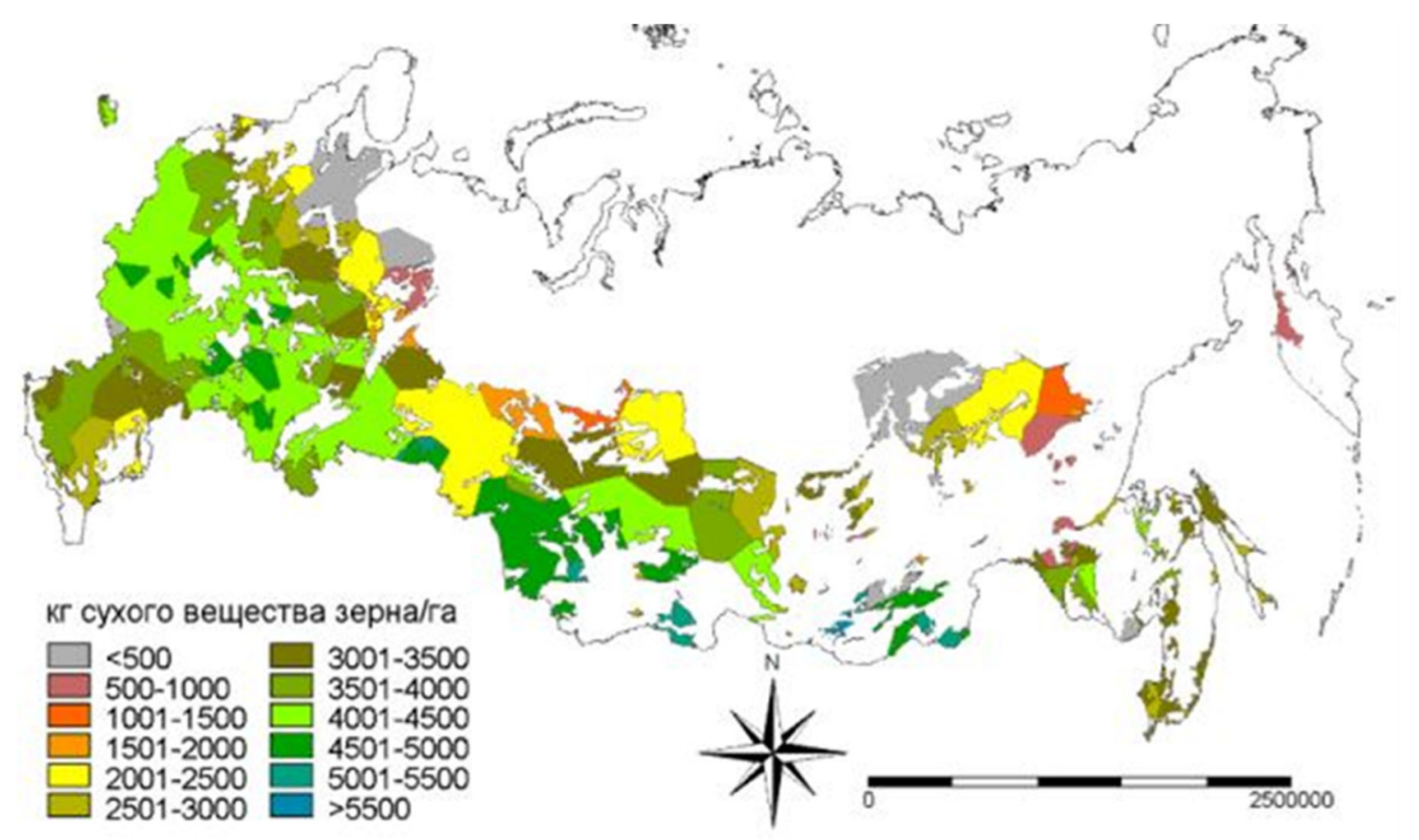

Рис. 1. Районирование земель с потенциальной продуктивностью

Система ЕФИС ЗСН вобрала в себя инновационный и диверсифицированный подход к районированию землепользования для отражения различных требований к пространственному планированию посредством инновационного многопланового зонирования земель [4].

Планирование пространства является основой для подготовки и осуществления контроля использования земель, поэтому управление районированием земель требует принятия различных типов классификации зон для удовлетворения различных требований к пространственному планированию (рис. 2). 
Вместе с тем все трудности формирования единого государственного подхода к земельным ресурсам как основе социально-экономического развития государства обусловлены тем, что действующее законодательство носит разрозненный характер и направлено на регулирование использования земельных участков и территориальных зон различного назначения, а не земельных ресурсов в его границах.

Результатом такой ситуации является неопределенность в правовом регулировании земельных отношений, отсутствие единой правоприменительной практики в отношении земельной политики, которая фактически остается фрагментированной в государственных ведомствах. В связи с этим при принятии управленческих решений возникают конфликты и разногласия, что делает практически невозможным создание системы государственного управления в рамках рационального землепользования.

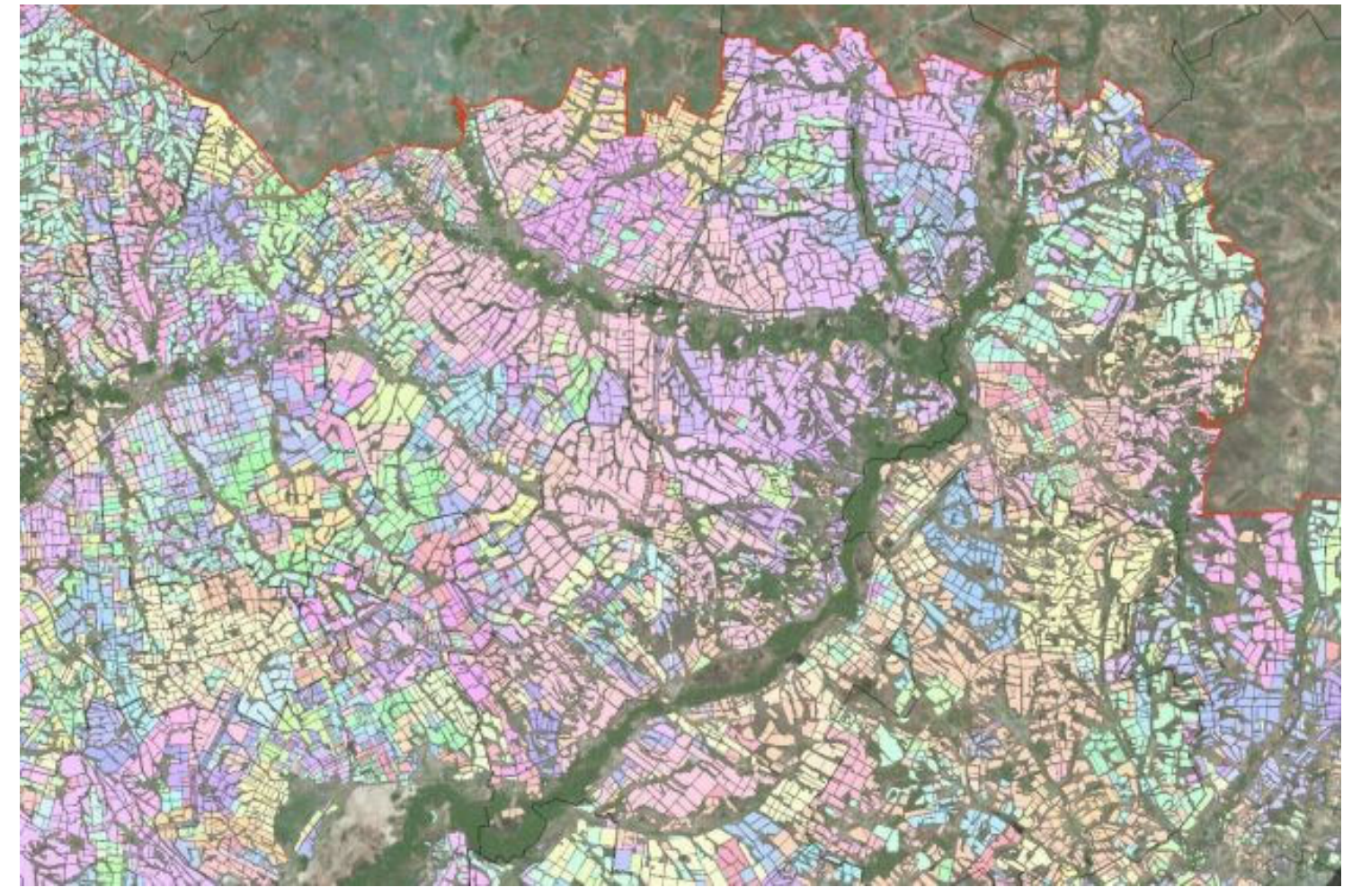

Рис. 2. Информационная система мониторинга с/х угодий

Элементы планирования в использовании земель должны стать частью государственного стратегического курса на повышение социально-экономического развития отдельных территорий для стабилизации ситуации в целом по стране, кроме того в последствии их отражение необходимо найти в нормативно-правовых актах, регулирующих земельные отношения.

Федеральный закон от 28.06.2014 № 172-Ф3 не содержит норм формирования единообразной структуры для принятия нормативных актов в сфере земельно-имущественных отношений, учитывающей связь с важными линиями стратегического планирования с другими отраслями законотворческой деятельности. 
Многие из применяемых в настоящее время в нашей стране стандартов классификации и стандартизации землепользования были разработаны в рамках прежней системы управления разделением природно-ресурсного сектора и не отвечают современным и перспективным требованиям и тенденциям развития единого природопользования.

Построение устойчивой системы классификации землепользования будет является ключом к оптимизации структуры и компоновки территориального пространства, а также основой для адаптации к единому управлению природными ресурсами $[5,6]$.

При традиционном планировании землепользования основное сосредоточение заложено на сохранении ресурсов земель сельскохозяйственного назначения, что отражается в содержании норм законодательной базы государственного контроля, в рамках перехода из категории земель сельскохозяйственного назначения в иные категории, при этом игнорируя защиту экологической среды и охраны земель. Рассмотрев новую классификацию землепользования, которая должна служить глобальному управлению типом использования, в основе которого лежит переход от одноэлементной защиты пахотных земель к защите всех элементов [7].

Построение многоуровневой системы зонирования формирования ландшафта стратификации с учетом кластерного развития, таксономической охраны. Переход от текущего одноуровневого зонирования регулирования землепользования к многоуровневому зонированию регулирования землепользования может и должен включать несколько уровней зонирования.

Для устойчивого курса развития рационального использования и охраны земель необходимо найти отражение в нормативно-правовых актах, а деятельность землепользователей и собственников земельных угодий не должна противоречить принятым федеральным нормам ведь земля является основой жизни и деятельности народов согласно Конституции Российской Федерации.

Государственную политику в области рационального использования земельных ресурсов необходимо рассматриваться как часть основанной на Конституции Российской Федерации единой социально-экономической политики. Упорядочение государственной земельной политики не может быть осуществлено без установления законодательно-правовых основ деятельности государства в области рационального использования земельных ресурсов. На уровне федеральных законов должны быть определены понятия, основные цели, задачи и инструменты государственной политики в сфере рационального использования земельных ресурсов. Важно подчеркнуть подчиненность деятельности органов государственной власти закону для осуществления стратегического планирования и реализации государственной социально-экономической политики, преодоления разобщенности нормативно-политических основ регулирования земельных отношений и законодательных норм. 


\section{БИБЛИОГРАФИЧЕСКИЙ СПИСОК}

1. Аверьянова Н.Н. Конституционно-правовое регулирование земельных отношений в Российской Федерации: монография / под ред. Г.Н. Комковой. М., 2017. С. 114-116.

2. Галиновская Е.А. Концепция государственного стратегического управления земельными ресурсами (правовой аспект) // Вопросы государственного и муниципального управления. 2017. № 3. С. 62-63.

3. Кочнева И.В. Политико-правовые способы и механизмы управления земельными ресурсами в России // Государственная власть и местное самоуправление. 2014. № 12. С. 18-21.

4. Харьков В.Н. Правовые основы государственной земельной политики // Правовые вопросы недвижимости. 2013. № 1. С. 98-99.

5. Чуднова Е.И. Стратегическое планирование в сфере использования земельного фонда: Россия и Шотландия, опыт сопоставления // Юрист. 2018. № 4. С. 55-58.

6. Министерство сельского хозяйства Российской Федерации. Государственный мониторинг земель сельскохозяйственного назначения. [Электронный ресурс] - 2018. - С. 5-8 Режим доступа: https://www.akkor.ru/sites/default/files/i.s.kozubenko.pdf. - Загл. с экрана.

7. Википедия [Электронный ресурс]/ свободная энциклопедия 2000-2020. Режим доступа: https://ru.wikipedia.org/wiki/Территориальное_планирование. - Загл. с экрана.

(С) Д. В. Морошкин, 2021 